ISSN 2080-5993

e-ISSN 2449-9811

\author{
Jan Kaczmarzyk \\ University of Economics in Katowice \\ e-mail: jan.kaczmarzyk@ue.katowice.pl
}

\title{
PROSPECTIVE FINANCIAL ANALYSIS \\ WITH REGARD TO ENTERPRISE RISK EXPOSURE - THE ADVANTAGES OF THE MONTE CARLO METHOD
}

\section{PROSPEKTYWNA ANALIZA FINANSOWA Z UWZGLĘDNIENIEM RYZYKA PRZEDSIĘBIORSTWA - ZALETY PODEJŚCIA MONTE CARLO}

DOI: $10.15611 /$ nof.2016.2.02

JEL Classification: G32

Summary: Prospective financial analysis is a key decision tool in an enterprise. The traditional approach confronts the forecasted value of a financial category or a financial ratio with a requirement or a standard. Knowing that the particular category or the ratio meets the requirement or the standard is a kind of risk information, but realizing that the requirement or the standard is met with a particular probability level is a detailed image of risk. The aim of the paper is to indicate the possibility to increase the effectiveness of prospective financial analysis by using a Monte Carlo simulation. The biggest advantage of the presented approach (that is in fact the evolution of the traditional scenario approach to risk analysis) is that it delivers the detailed probability distributions of key financial categories and ratios. Shareholders accepting the results of prospective financial analysis with the Monte Carlo simulation should accept risk in a more conscious way than in the case of the traditional approach.

Keywords: corporate finance, financial analysis, risk, Monte Carlo, forecasting.

Streszczenie: Celem prospektywnej analizy finansowej jest dostarczenie prognozowanych wartości kluczowych kategorii i wskaźników finnansowych. W zmiennym otoczeniu konieczne jest jednak rozważenie ekspozycji działalności gospodarczej przedsiębiorstwa na ryzyko. Prognozowane poziomy kategorii lub wskaźników finansowych stanowiących zmienne ryzyka - same w sobie - mogą być sygnałem o narażeniu przedsiębiorstwa na określony rodzaj ryzyka. Dysponowanie pojedynczym scenariuszem nie pozwala jednak na ocenę zmienności. Właściwym rozwiązaniem jest określenie rozkładów prawdopodobieństwa kategorii lub wskaźników finansowych. Uzyskanie dokładnego rozkładu prawdopodobieństwa zmiennej ryzyka stanowiącej prognozowaną kategorię lub wskaźnik finansowy w prospektywnej analizie finansowej umożliwia metoda Monte Carlo. Celem artykułu jest wskazanie możliwości zwiększenia skuteczności prospektywnej analizy finansowej przez wykorzystanie symulacji Monte Carlo.

Słowa kluczowe: finanse przedsiębiorstwa, analiza finansowa, ryzyko, Monte Carlo, prognozowanie. 


\section{Introduction}

Individuals responsible for managing corporate finance often face the problem of making decisions with regard to risk. Thus, they look for effective risk assessment tools. Prospective financial analysis is the most popular decision tool in an enterprise. The results of prospective financial analysis are forecasted values of financial categories and ratios. The traditional approach to prospective financial analysis confronts the forecasted value of a category or a ratio with a requirement or a standard, which seems to be an inadequate solution. Knowing that the particular category or the ratio meets the requirement or the standard is a kind of risk information, but realizing that the requirement or the standard is met with a particular probability level, or what are the possible extreme values is a detailed image of risk. Hence, it seems to be important to indicate a Monte Carlo simulation as an adequate risk assessment tool. Involving a Monte Carlo simulation in any prospective financial analysis brings probability distributions of financial categories and ratios, thus enabling decision under the criterion of risk. Taking into account the above, the aim of the paper is to indicate the possibility to increase the effectiveness of prospective financial analysis by using a Monte Carlo simulation.

\section{Prospective financial analysis with regard to risk - the answer to risk acceptance dilemma}

Managing a modern enterprise focuses on managing its market value. Such a phenomenon is a consequence of the widely accepted paradigm describing the aim of any entrepreneurial activity of any modern enterprise as creating value for shareholders. Focusing on the value is the evolution of the traditional approach that emphasized the major role of maximizing earnings (net income), or more precisely, maximizing earnings in relation to own equity value [Gorczyńska 2013, p. 100]. Generated earnings are obviously the primary source of shareholders' wealth on the one hand, whereas they determine the profitability of an enterprise on the other, being the most important factor of market value creation [Łukasik (ed.) 2004, p. 15].

Shareholders are typically willing to give equity they own to the enterprise, as far as it guaranties an accepted rate of return. The rate of return should compensate the level of risk to be taken by becoming involved [Chapman 2006, p. 8]. The transfer of equity should have been the consequence of risk acceptance. The question is how exactly modern shareholders accept the risk of entrepreneurial activity of an enterprise (especially when it comes to accepting risk of an enterprise that is not listed on a capital market).

Listed companies are being valued constantly as a consequence of constant transactions on the capital market. As a result, shareholders are able to monitor the market value of shares and assess the effectiveness of activities undertaken by 
the boards and to accept the volatility of shares over time. The only problem is whether the price of the share reflects the true value of the particular enterprise in the particular time. Non-listed companies are valued from time to time, usually not on a regular basis. Therefore, risk acceptance in terms of the market value of a nonlisted enterprise needs designated financial analyses.

The market value is not the only core financial category whose volatility matters. The volatility of profitability, liquidity etc. has significant meaning too. In fact, shareholders of listed companies do not have the direct possibility to accept the volatility of any other important financial category or ratio than the market value. Shareholders of non-listed companies do not even have that. The proper approach to financial analysis could be a solution.

Financial analysis operates on historical financial statements and financial forecasts. Financial forecasts are in fact simplified financial statements reflecting the expected state of the economic environment built on the basis of historical information. A shareholder interested in sharing equity is able, on the basis of historical and projected financial statements, to perform historical and prospective financial analysis including:

- preliminary financial analysis of the core financial categories structure and dynamics,

- financial ratios analysis reflecting profitability, liquidity, debt and debt service ability, activity efficiency, with regard to their dynamics,

- market value assessment using free cash flows or another approach.

Performing a historical financial analysis does not need a computer financial model of an enterprise, whereas a prospective financial analysis does. The quality of the financial model determines the quality of the prospective financial analysis.

Financial analyses (both historical and prospective) preceded by the strategic analysis of entrepreneurial activity in terms of constantly changing environment, bring initial information about risk only (especially information about chances and threats as a consequence of identified risk factors influence). Knowing risk sources raises the risk awareness of shareholders but only allows the shareholders to partially accept risk. Full risk acceptance requires risk quantification, which leads to the probability distributions of core financial categories and ratios. Probability distributions describe precisely the financial categories and ratios in terms of their volatility. Only knowing how volatile core financial categories and ratios (e.g. expected earnings, cash flows, profitability ratios, market value etc.) might be, allows shareholders to accept risk in the best possible way. Incorporating risk analysis using Monte Carlo methods is a suitable solution to bring a probability distribution of a financial category or ratio as the result of prospective financial analysis. 


\section{A concept of the Monte Carlo approach to prospective financial analysis with regard to risk}

The basic result of the forecasting process in an enterprise is a scenario of entrepreneurial activity. Taking into consideration the volatility of the economic environment, an individual responsible for forecasting should assume that there is much more than one scenario possible to occur. Building scenarios is an important but, at the same time, a very limited tool. Although an individual is able to give a few scenarios that significantly differ and represent different forecasted states of the economic environment (e.g. very negative, negative, expected, positive and very positive etc.), it is hard and very time-consuming to give every possible scenario that can possibly occur in practice. The limited number of scenarios is not the only disadvantage of the scenarios method [Rogowski 2008, p. 270]. The other important disadvantage is a subjectively given probability of scenarios. As a result, the scenario method gives the probability distribution of relatively poor quality. The Monte Carlo approach $^{1}$ in risk analysis shall be perceived as an evolution of the traditional scenario analysis [Brealey, Myers, Marcus 2001, p. 473]. Monte Carlo tries to consider as many possible-to-happen [Vose 2008, p. 63] scenarios as possible, thus giving more detailed probability distribution of risk variable (Figure1).

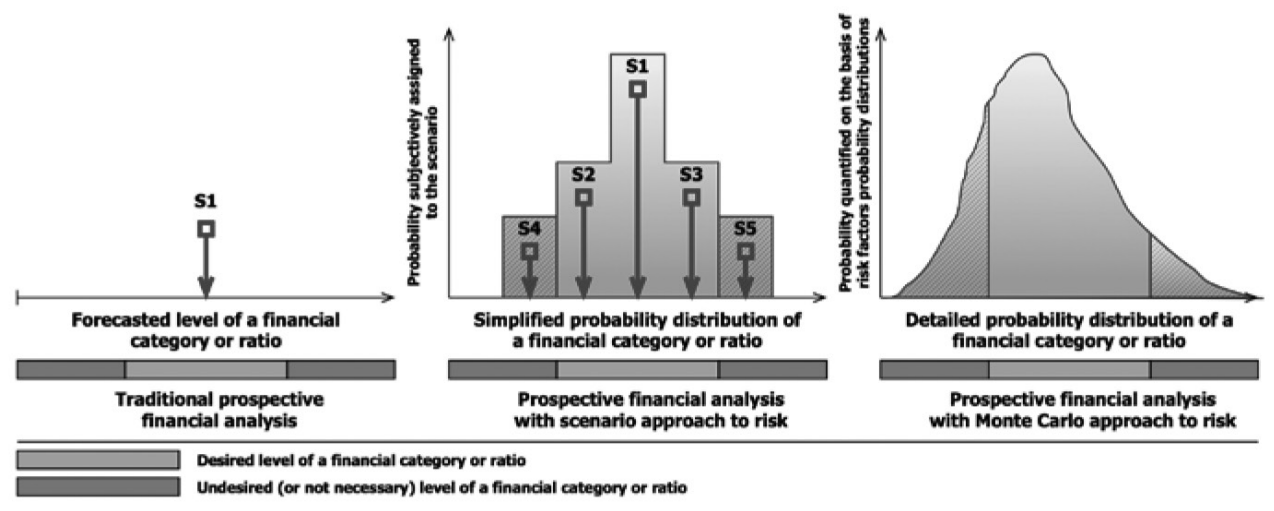

Fig. 1. The basic advantage of the Monte Carlo approach in prospective financial analysis

Source: own study.

Simulation is the core element of the Monte Carlo approach. The outcome of each simulation is a scenario of risk factors generated randomly with regard to

${ }^{1}$ The Monte Carlo method or simulation is sometimes defined as simulation analysis [Fabozzi, Peterson 2003, p. 464; Brealey, Myers, Marcus 2001, p. 473] or probabilistic simulation [Helfert 2001, p. 287]. 
their probability distributions. Randomly generated scenarios are processed in the financial model developed for a particular decision problem in order to calculate corresponding risk variables values [Vose 2008, p. 45; Rees 2008, p. 137; Hertz 1964 , p. 102]. The more scenarios generated, the more accurate the outcome is. The key problem of the simulation is to reflect the close-to-reality behaviour of the risk factors. Automatically, the risk factors' changes in a Monte Carlo simulation are simultaneous and non-linear, that is close to real economic conditions. Due to advanced techniques, the changes of risk factors may also be interdependent [Vose 2008, pp. 353-392]. There are many solutions available in terms of getting risk factor changes interrelated but it seems that Cholesky's decomposition [Wilmott 2006, pp. 1275-1276] is, for example, the easiest to be implemented in spreadsheets [Kaczmarzyk 2016, pp. 102-104]2.

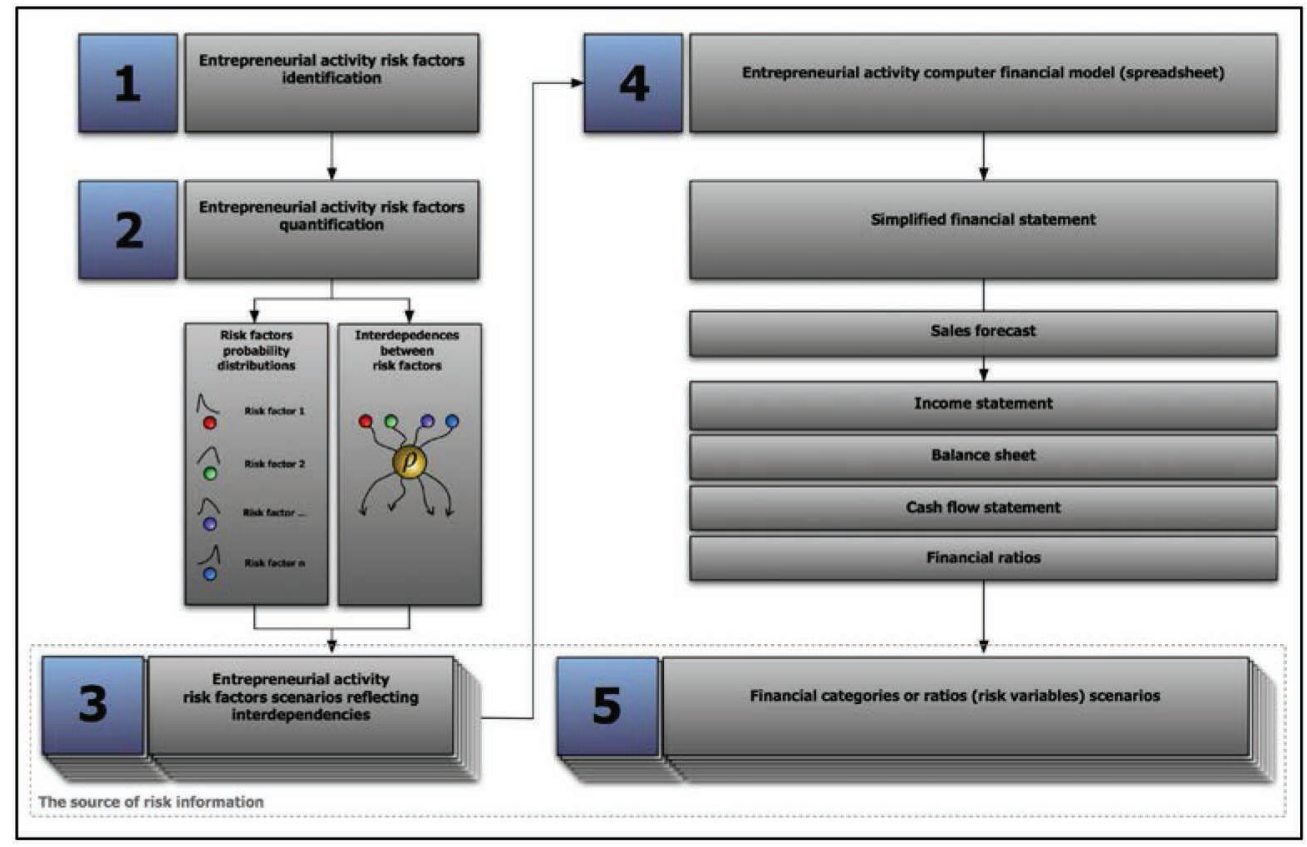

Fig. 2. The Monte Carlo approach for prospective financial analysis

Source: own study.

In prospective financial analysis, the procedure of the Monte Carlo risk analysis (Figure 2) starts with the identification (1) and quantification (finding probability

${ }^{2}$ There are also many professional add-ins for spreadsheets (e.g. Palisade @ RISK, Vose Software ModelRisk) which enable a Monte Carlo simulation with the assumption that risk factors are interdependent. 
distributions and correlations) of risk factors (2). The most important problem in quantification is the source of information - some risk factors have historical data whereas others do not. Due to the availability, quality and adequacy of historical data [Vose 2008, p. 393], an individual responsible for risk analysis can consider objective (direct use of historically attained probability distributions types and parameters), quasi-objective (indirect use of historically attained probability distributions by modifying their parameters) or a subjective way (use of special distribution types with an expert opinion as a primary source of information) of risk factor quantification [Kaczmarzyk 2013, p. 25]. The next step is to generate random scenarios of risk factors (3) with regard to assumed probability distributions and correlations. After that, the generated scenarios are processed in a financial model of an enterprise being a simplified financial statement (4) to find corresponding scenarios of risk variables (5) being key financial categories (e.g. EBIT, EAT, FCFF, FCFE etc.) or ratios (e.g. liquidity, debt, profitability ratios etc.).

The scenarios of risk factors and variables are the source of possible enterprise risk measurements. As far as the financial model in use is actually a simplified financial statement (including income statement, balance sheet and cash flows), there are numerous financial categories and ratios - describing particular areas of entrepreneurial activity in numerous ways - available to choose. The scenarios attained through the Monte Carlo simulation are the source of probability distributions of financial categories and ratios (risk variables) together with risk factors probability distributions.

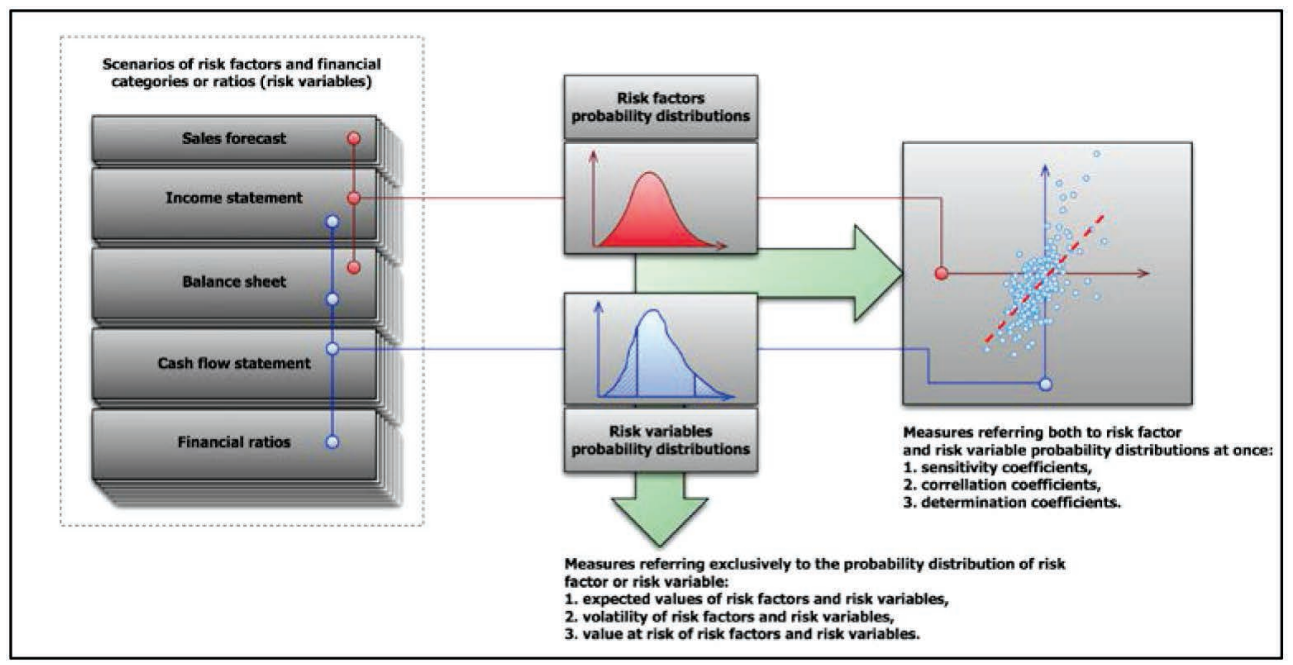

Fig. 3. The results of prospective financial analysis with the Monte Carlo approach to reflect risk Source: own study on the basis of [Zieliński 2010, pp. 43-50; Jajuga (ed.) 2007, pp. 33-51]. 
Prospective financial analysis with regard to risk can be based on two groups of statistical measures of risk. The first group references exclusively to the probability distribution of risk factor or risk variable. These measures enable the assessment of risk factor or risk variable expected value (usually average value), volatility (usually standard deviation) or value at risk. The second group that refers both to risk factor and risk variable probability distributions at the same time, enables the assessment of risk variable reaction to risk factor change in terms of reaction direction and scale (sensitivity coefficient). The second group also informs us how much risk factor changes explain risk variable changes (coefficient of determination) (Figure 3).

In addition to typical statistical measures, the probability distributions of financial categories and ratios inform about probability that their optimum values or ranges are to be maintained [Helfert 2001, p. 287]. Adding risk exposure to financial categories or ratios extends prospective financial analysis to be a tool enabling individuals responsible for enterprise management and shareholders to consciously and actually accept risk. In other words, they can accept not only the particular levels of financial categories and ratios but their tendency to change as well. Of course the traditional approach in prospective financial analysis offers a kind of risk information, because financial categories or ratios that do not match standards, become signs of risk. The simulation approach, additionally, informs about the chance that they are able to match these standards, which seems to be the biggest advantage of the Monte Carlo approach in prospective financial analysis (see Figure 1).

In terms of sensitivity analysis, the Monte Carlo approach can be perceived as an extension of traditional sensitivity analysis [Helfert 2001, p. 287], which takes up the non-realistic assumption that only one risk factor changes at one time (nonsimultaneous, non-interdependent changes of risk factors) and the probability of any deviation from risk factor expected value is the same (linear changes of risk factors) [Kaczmarzyk, Zieliński 2010, p. 173]. A typical sensitivity analysis 'becomes unmanageable if we change several factors at the same time' [Fabozzi, Peterson 2003 , p. 464]. The most common examples of typical sensitivity analysis include degrees of operating (DOL) and financial leverage (DFL). Using the Monte Carlo simulation one can observe the behaviour of enterprise earnings under the influence of multiple risk factors at the same time (instead of assessing the reaction of earnings to changing sales like with DOL and DFL, it is possible to assess the reaction of earnings to changing prices, demand, currency exchange rates, interest rates and others at the same time). The simulation approach to sensitivity analysis gives easierto-interpret results if scenarios including risk factors and variables potential values are transformed into percentage changes [Kaczmarzyk, Zieliński 2010, pp. 176-184] versus initial or expected values. 


\section{Case study}

The first part of a prospective financial analysis with regard to risk using the Monte Carlo approach involves building a convenient financial model of the entrepreneurial activity of an enterprise. There are several solutions in spreadsheets available [Sengupta 2010; Proctor 2010; Rees 2008; Benninga 2008; Tjia 2004; Day 2003]. The idea behind the model of an enterprise is to bring forecasted, close to reality, financial statements including income statement, balance sheet and cash flow statement. The forecasting of variable revenues results in the difference between total forecasted assets and total forecasted liabilities. Closing balance sheet becomes a comprehensive point when possible necessary to finance or surplus fund generates interest. An iterative solution can be achieved in a spreadsheet through cyclic addressing [Benninga 2008, p. 109; Tjia 2004, pp. 119-143] or through a proprietary Visual Basic for Application procedure.

The model prepared for the case study (see Appendix) consists of production schedule, fixed assets depreciation schedule, long term loan schedule, income statement, balance sheet and financial ratios (liquidity, profitability and debt ratios). The financial projection was set to 10 years and followed by detailed assumptions in terms of entrepreneurial activity, based on opening balance sheet values (Table 1).

Table 1. Case study - assumptions for forecast

\begin{tabular}{|c|c|c|}
\hline \multirow{2}{*}{ Input variable } & \multicolumn{2}{|c|}{ Value } \\
\hline & $t_{0}-$ initial & $t_{(1, n)}-$ forecasted \\
\hline 1 & 2 & 3 \\
\hline Annual demand changes & & $2.0 \%(\mathrm{RF} 1)$ \\
\hline Production / demand & $5,000.0 \mathrm{pcs}$ & \\
\hline Production capabilities & $5,000.0 \mathrm{pcs}$ & \\
\hline $\begin{array}{l}\text { Percentage change of relation between fixed } \\
\text { assets and production capabilities } \\
\text { (new / additional fixed assets) }\end{array}$ & & $0.0 \%$ \\
\hline $\begin{array}{l}\text { Relation between fixed assets and production } \\
\text { capabilities }\end{array}$ & $90.00 \mathrm{PLN} / \mathrm{pcs}$ & 90.00 PLN/pcs (RF2) \\
\hline Present value of fixed assets & $390,000.00$ PLN & \\
\hline $\begin{array}{l}\text { Average depreciation rate } \\
\text { (for t } 0 \text { depreciation to present value of fixed } \\
\text { assets) }\end{array}$ & $7.0 \%$ & $7.0 \%$ \\
\hline Depreciation & $27,300.00$ PLN & \\
\hline Capital expenditures - fixed assets replacement & $23,000.00$ PLN & \\
\hline Fixed assets with depreciation & 280,000.00 PLN & \\
\hline Debt value & $150,000.00$ PLN & \\
\hline Debt payments & 8 & \\
\hline
\end{tabular}


$\underline{\text { Prospective financial analysis with regard to enterprise risk exposure... }}$

\begin{tabular}{|c|c|c|}
\hline 1 & 2 & 3 \\
\hline Percentage change of unit price & & $0.0 \%$ \\
\hline $\begin{array}{l}\text { Unit price } \\
\text { (for } t_{0} \text {, net revenues from sales to demand) }\end{array}$ & $210.00 \mathrm{PLN} / \mathrm{pcs}$ & 210.00 PLN/pcs (RF3) \\
\hline Net revenues from sales & $1,050,000.00$ PLN & \\
\hline Percentage change of unit variable cost & & $0.0 \%$ \\
\hline $\begin{array}{l}\text { Unit variable cost } \\
\text { (Overall variable cost to demand) }\end{array}$ & $170.00 \mathrm{PLN} / \mathrm{pcs}$ & $170.00 \mathrm{PLN} / \mathrm{pcs}(\mathrm{RF} 4)$ \\
\hline Overall variable cost & $850,000.00$ PLN & \\
\hline Percentage change of fixed cost & & $0.0 \%$ \\
\hline Fixed costs & $100,000.00$ PLN & $100,000.00$ PLN (RF5) \\
\hline Financial revenues & 2,500.00 PLN & \\
\hline Financial costs & $3,500.00$ PLN & \\
\hline Inventory & 120,000.00 PLN & \\
\hline Receivables & $80,000.00$ PLN & \\
\hline Short term investment (with financial revenues) & $40,000.00$ PLN & \\
\hline $\begin{array}{l}\text { Short term investment (cash and current } \\
\text { accounts) }\end{array}$ & $10,000.00$ PLN & \\
\hline Equity & $100,000.00$ PLN & $100,000.00$ PLN \\
\hline Net income & $61,923.00$ PLN & \\
\hline Short term liabilities (bank credits) & $100,000.00$ PLN & \\
\hline Short term liabilities & $60,000.00$ PLN & \\
\hline Long term debt interest rate & \multicolumn{2}{|c|}{$5 \%$} \\
\hline Short term investment interest rate & \multicolumn{2}{|c|}{$1 \%$} \\
\hline Short term debt interest rate & \multicolumn{2}{|c|}{$7 \%$} \\
\hline Effective tax rate & \multicolumn{2}{|c|}{$19 \%$} \\
\hline Dividend rate & \multicolumn{2}{|c|}{$30 \%$} \\
\hline Inventory cycle (in days of sales) & \multicolumn{2}{|c|}{41.71} \\
\hline Receivables cycle (in days of sales) & \multicolumn{2}{|c|}{27.81} \\
\hline Short term liabilities cycle (in days of sales) & \multicolumn{2}{|c|}{20.86} \\
\hline $\begin{array}{l}\text { Short term investment (cash and current } \\
\text { accounts) cycle (in days of sales) }\end{array}$ & \multicolumn{2}{|c|}{3.48} \\
\hline
\end{tabular}

Source: own study.

The risk factors taken into account include: annual demand change (RF1), relation between fixed assets and production capabilities (RF2), unit price (RF3), variable unit cost (RF4) and fixed costs (RF5) for $t_{1}\left(t_{2}\right.$ to $t_{10}$ are equal to $\left.t_{1}\right)$. The assumptions were made using normal probability distribution (RF1), uniform probability distribution (RF2) and a pert probability distributions (RF3, RF4 and RF5) using the subjective approach [Vose 2008, pp. 404-407] (Table 2). 
Table 2. Case study - assumptions for risk analysis

\begin{tabular}{|c|c|c|c|c|c|c|c|c|c|}
\hline Name & Formula & Distribution & Minimum & Maximum & Mean & Mode & St. Dev. & $5 \%$ & $95 \%$ \\
\hline RF1 & $=\operatorname{RiskNormal}(2 \% ; 2 \%)$ & & $-5.1 \%$ & $9.3 \%$ & $2.0 \%$ & $1.9 \%$ & $2.0 \%$ & $-1.3 \%$ & $5.3 \%$ \\
\hline RF2 & $=$ RiskUniform $(80 ; 100)$ & & 80.00 PLN & 100.00 PLN & 90.00 PLN & 80.70 PLN & 5.77 PLN & 81.00 PLN & 99.00 PLN \\
\hline RF3 & $=\operatorname{RiskPert}(200 ; 210 ; 215)$ & & 200.64 PLN & 214.89 PLN & 209.17 PLN & 210.24 PLN & 2.76 PLN & 204.30 PLN & 213.36 PLN \\
\hline RF4 & $=$ RiskPert $(165 ; 170 ; 180)$ & & 165.07 PLN & 179.46 PLN & 170.83 PLN & 170.22 PLN & 2.76 PLN & 166.64 PLN & 175.69 PLN \\
\hline RF5 & $\begin{array}{l}=\text { RiskPert }(90000 ; 100000 \\
110000)\end{array}$ & & $\begin{array}{c}90,386.65 \\
\text { PLN }\end{array}$ & $\begin{array}{l}109,702.65 \\
\text { PLN }\end{array}$ & $\begin{array}{l}100,000.08 \\
\text { PLN }\end{array}$ & $\begin{array}{c}99,733.22 \\
\text { PLN }\end{array}$ & 3,780.06 PLN & $\begin{array}{l}93,781.00 \\
\text { PLN }\end{array}$ & $\begin{array}{l}106,212.89 \\
\text { PLN }\end{array}$ \\
\hline
\end{tabular}

Source: own study.

Interdependency between RF1 and RF3 was set to -0.95 of linear coefficient, meaning the lower the unit price, the larger the annual increase of demand. Monte Carlo simulation output risk variables include return on equity ratio (ROE), return on assets ratio (ROA), current liquidity ratio (CLR) and overall debt ratio (ODR) for $\mathrm{t}_{1}$ and $\mathrm{t}_{3}$ forecasted periods. The simulation resulted in 5,000 scenarios, reflecting the interdependency generated using Latin Hypercube sampling ${ }^{3}$.

Let the desired level of ROE be between $10 \%$ and $20 \%$. In $t_{1}$ the probability to meet the desired level is $58.5 \%$ whereas in $t_{3}-89.2 \%$. The increase is mainly caused by repaying long term debt responsible for the additional variability of net income. Very similar values of expected ROE (mode: $17.38 \%$ for $t_{1}$ and $17.54 \%$ for $t_{3}$ ) are then achieved with significantly lower volatility in $t_{3}$ (Figure 4 ). The ROA probability distribution moves positively (from $t_{1}$ to $t_{3}$ ), with mode increasing from $7.98 \%$ to $10.39 \%$, due to higher net income with similar volatility (Figure 5). If the desired level of ROA was from $8 \%$ to $15 \%$, then the actual ROA value would meet that requirement with $49.0 \%$ and $66.9 \%$ probability respectively in $t_{1}$ and $t_{3}$.

The distributions of the CLR as well as the ODR are very unique. The accepted level of CLR (Figure 6) is between 1.2 and 2.0 [Sierpińska, Jachna 2004, p. 147]. The ratio meets the standard with $79.1 \%$ of probability level in $t_{1}$ and with $41,2 \%$ in $t_{3}$. The top level of 2.0 is exceeded with $12.9 \%$ of probability in $t_{1}$ and with significantly higher level of $43.3 \%$ in $t_{3}$. Such changes in liquidity are the evidence of liquid assets significant surplus that could be involved in the entrepreneurial activity. The expected value is similar (mode: 1.378 for $t_{1}$ and 1.376 for $t_{3}$ ), whereas volatility (std.dev.: 0.376 for $t_{1}$ and 1.008 for $t_{3}$ ) is indicated as much higher. The much wider volatility range does not automatically resemble an inevitable situation.

\footnotetext{
${ }^{3}$ Random values were generated using Palisade @RISK 7.0. The number of simulations was chosen according to [Vose 2008, pp. 154-155].
} 


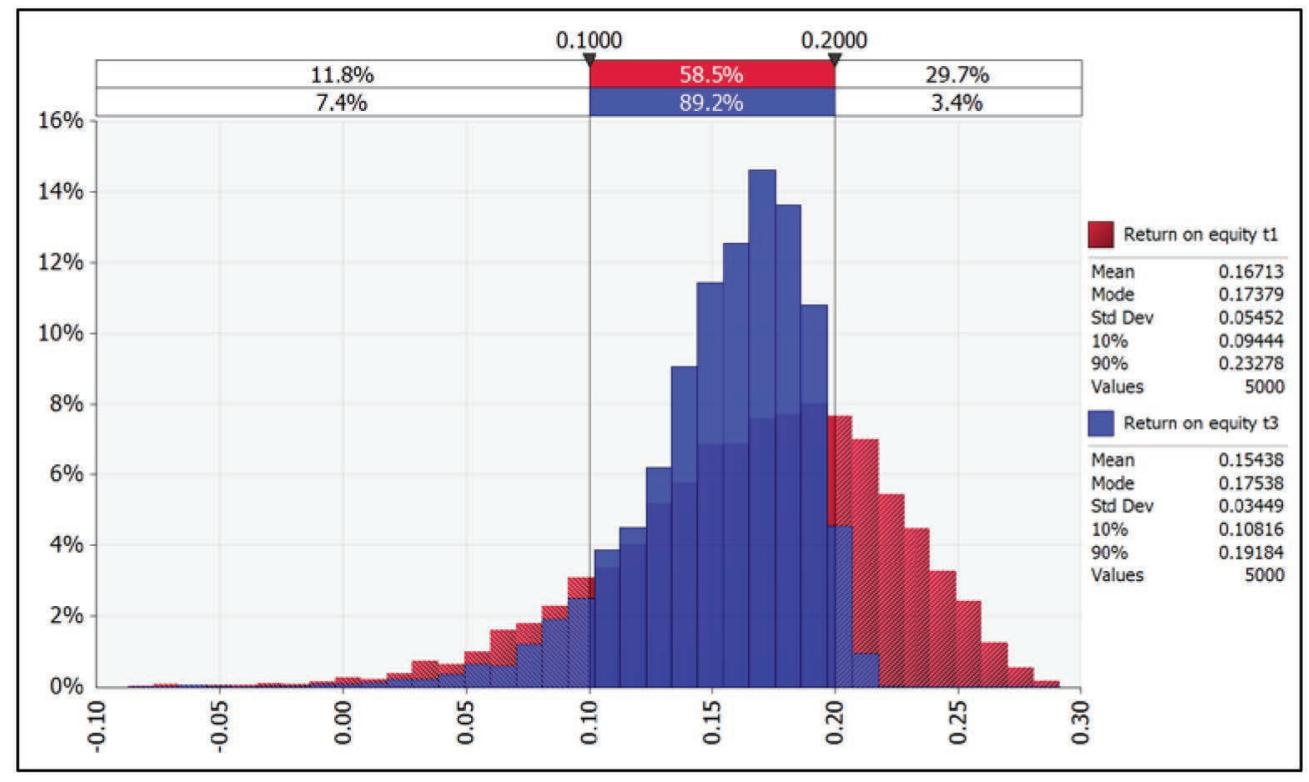

Fig. 4. Case study - return of equity for $t_{1}$ and $t_{3}$ Source: own study.

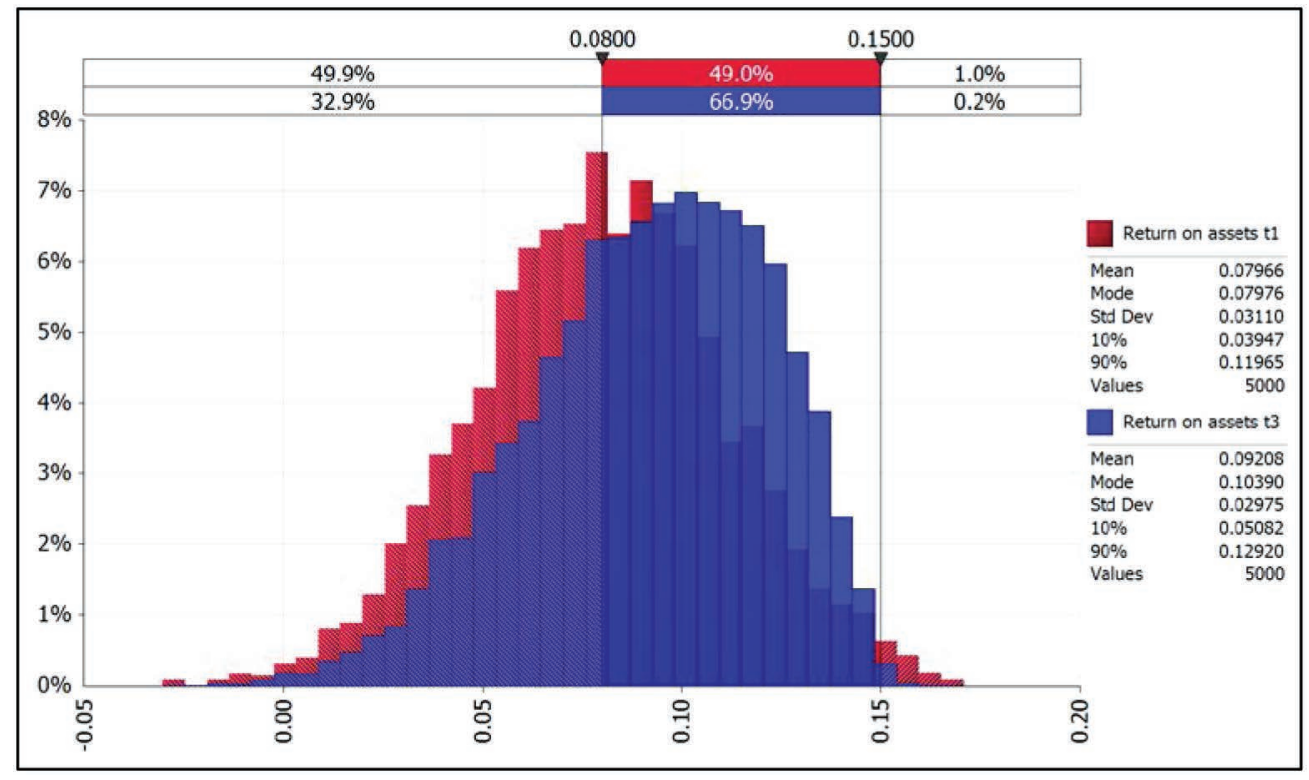

Fig. 5. Case study - return on assets for $t_{1}$ and $t_{3}$ Source: own study. 


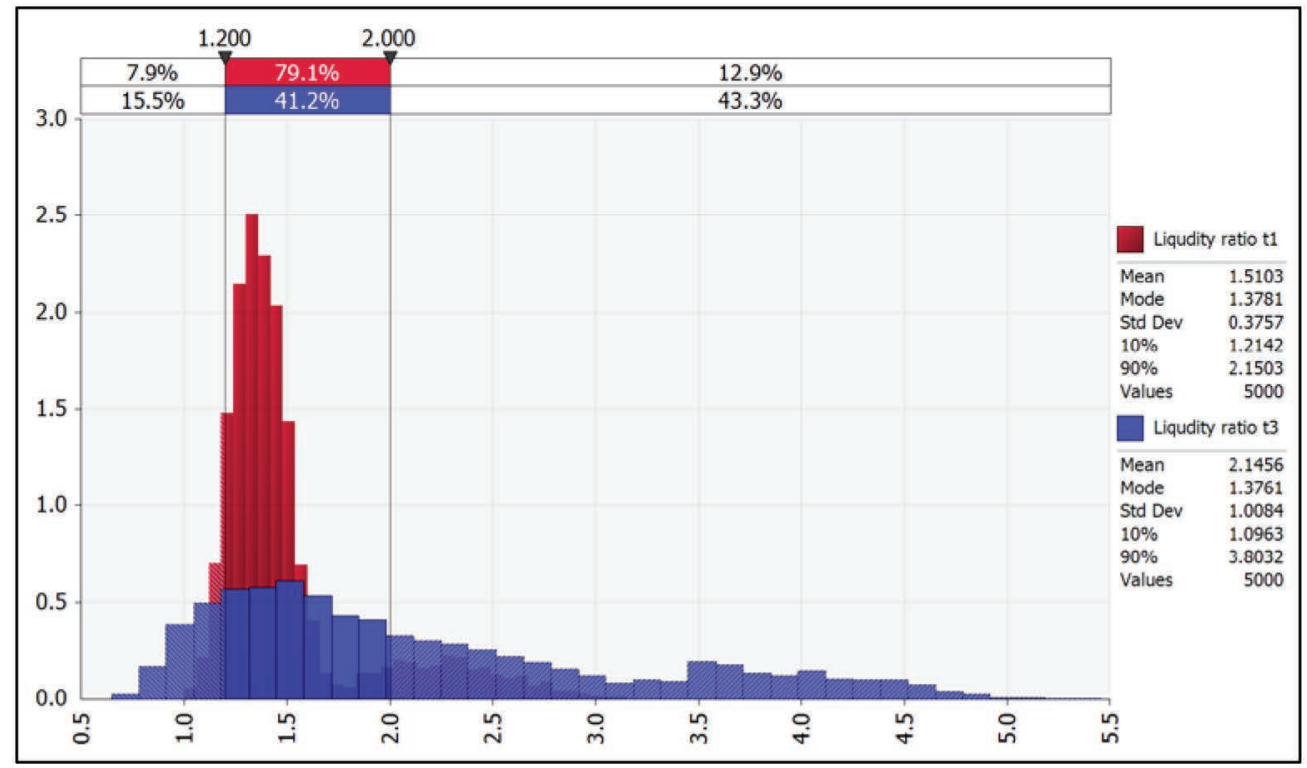

Fig. 6. Case study - current liquidity ratio for $t_{1}$ and $t_{3}$

Source: own study.

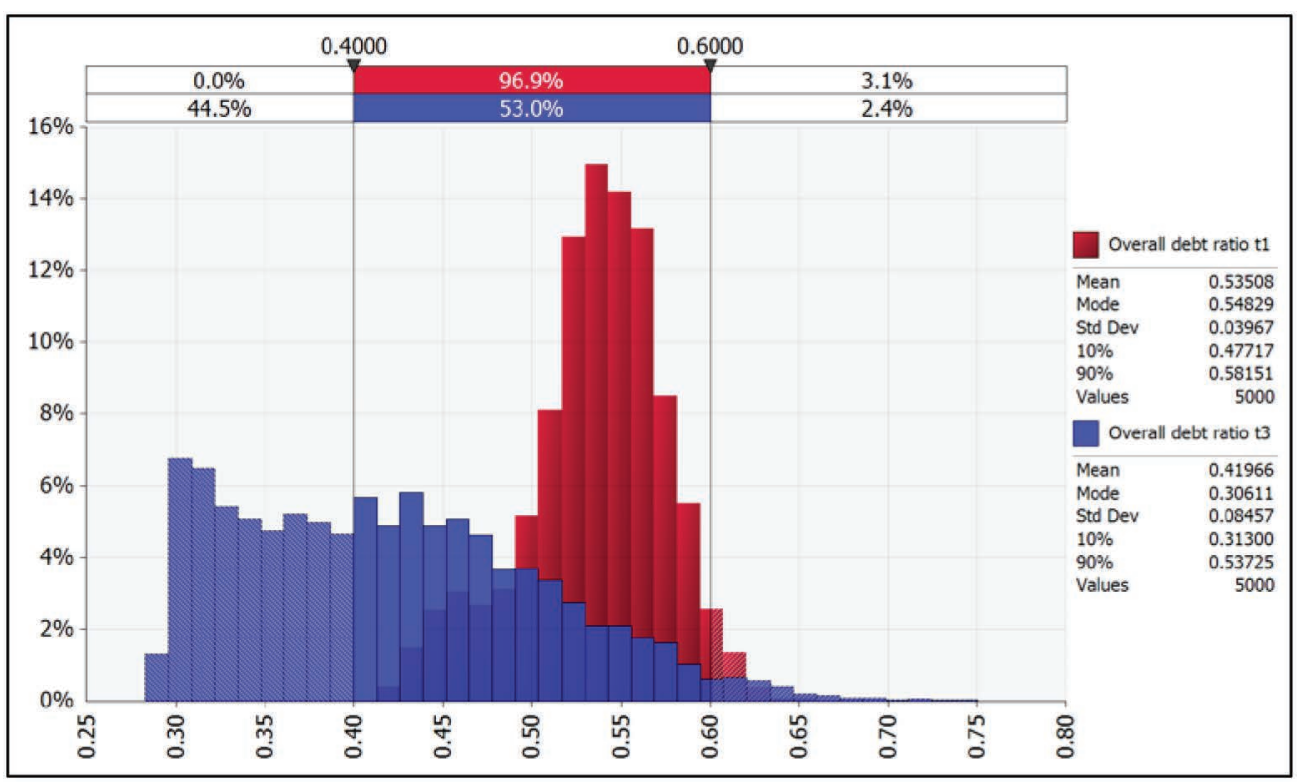

Fig. 7. Case study - overall debt ratio for $t_{1}$ and $t_{3}$

Source: own study. 
The distribution of the ODR (Figure 7) shows $44.5 \%$ probability of falling below 0.4 in $t_{3}$ in comparison to $0.0 \%$ in $t_{1}$. The repayment of debt is fixed in terms of a longterm part, whereas a short-term part depends on the actual situation of the enterprise. The higher the profitability, the lower the short-term financing level. The long-term part disappears due to assumptions over time. Therefore the ODR volatility range changes, with an expected value decreasing (mode: 0.548 for $t_{1}$ falls to 0.306 for $t_{3}$ ).

The Monte Carlo approach gives the distributions of financial ratios and the detailed information of meeting desired or accepted levels or ranges. The comparison of the distributions of risk factors and the distributions of financial ratios would additionally give the hierarchy of risk factors under the criteria of influence direction and scale. It would also show which risk factor and its changes explain the changes of financial ratios the most.

\section{Conclusions}

The Monte Carlo approach in prospective financial analysis delivers the detailed probability distributions of key financial categories and ratios. That is the biggest advantage of the presented approach (that is in fact the evolution of the traditional scenario approach to risk analysis). Any enterprise that employs the Monte Carlo simulation can check if particular categories and ratios can meet the requirements and standards for every single period of financial projection. As has been shown, financial distributions change over time, as well as does the entrepreneurial activity risk. Shareholders accepting the results of prospective financial analysis with the Monte Carlo simulation, accept risk in a more conscious way than in the case of the traditional approach.

\section{Bibliography}

Benninga S., 2008, Financial Modeling, The MIT Press, Cambridge.

Brealey R., Myers S., Marcus A., 2001, Fundamentals of Corporate Finance, McGraw-Hill, New York.

Chapman R., 2006, Simple Tools and Techniques for Enterprise Risk Management, John Wiley \& Sons, West Sussex.

Day A., 2003, Mastering Risk Modelling, FT Prentice Hall, Harlow.

Fabozzi F., Peterson P., 2003, Financial Management and Analysis, John Wiley \& Sons, New Jersey.

Gorczyńska M., 2013, Stabilność finansowa a zrównoważony rozwój przedsiębiorstwa, Journal of Management and Finance, no. 2, pp. 99-110

Helfert E., 2001, Financial Analysis Tools \& Techniques. A guide for managers, McGraw-Hill, New York.

Hertz D., 1964, Risk analysis in capital investment, Harvard Business Review, vol. 42, issue 1, pp. 95-106.

Jajuga K. (ed.), 2007, Zarzadzanie ryzykiem, PWN, Warszawa. 
Kaczmarzyk J., 2013, A subjective approach in risk modelling using simulation techniques, Studia Ekonomiczne Uniwersytetu Ekonomicznego w Katowicach, no. 127, pp. 23-34.

Kaczmarzyk J., 2016, Reflecting interdependencies between risk factors in corporate risk modeling using Monte Carlo simulation, Econometrics, no. 2, pp. 98-107.

Kaczmarzyk J., Zieliński T., 2010, Metody symulacyjne $w$ poszerzonej analizie wrażliwości, Studia Ekonomiczne Uniwersytetu Ekonomicznego w Katowicach, no. 71, pp. 171-187.

Łukasik G. (ed.), 2004, Strategie finansowe przedsiębiorstw w sytuacjach ryzykownych, Akademia Ekonomiczna w Katowicach, Katowice.

Proctor K., 2010, Building Financial Models with Microsoft Excel, John Wiley \& Sons, New Jersey.

Rees M., 2008, Financial modelling in practice, John Wiley \& Sons, West Sussex.

Rogowski W., 2008, Rachunek efektywności inwestycji, Oficyna Ekonomiczna/Wolters Kluwer Polska, Kraków.

Sengupta C., 2010, Financial Analysis and Modelling Using Excel and VBA, John Wiley \& Sons, New Jersey.

Sierpińska M., Jachna T., 2004, Ocena przedsiębiorstwa wedlug standardów światowych, PWN, Warszawa.

Tjia J., 2004, Building Financial Models, McGraw-Hill, New York.

Vose D., 2008, Risk Analysis. A Quantitative Guide, John Wiley \& Sons, West Sussex.

Wilmott P., 2006, Paul Wilmott on Quantitative Finance. Volume 3, John Wiley \& Sons, West Sussex.

Zieliński T., 2010, Ryzyko na rynku finansowym, [in:] Rynek finansowy, Pyka I. (ed.), Akademia Ekonomiczna w Katowicach, Katowice. 


\section{Appendix. Financial model}

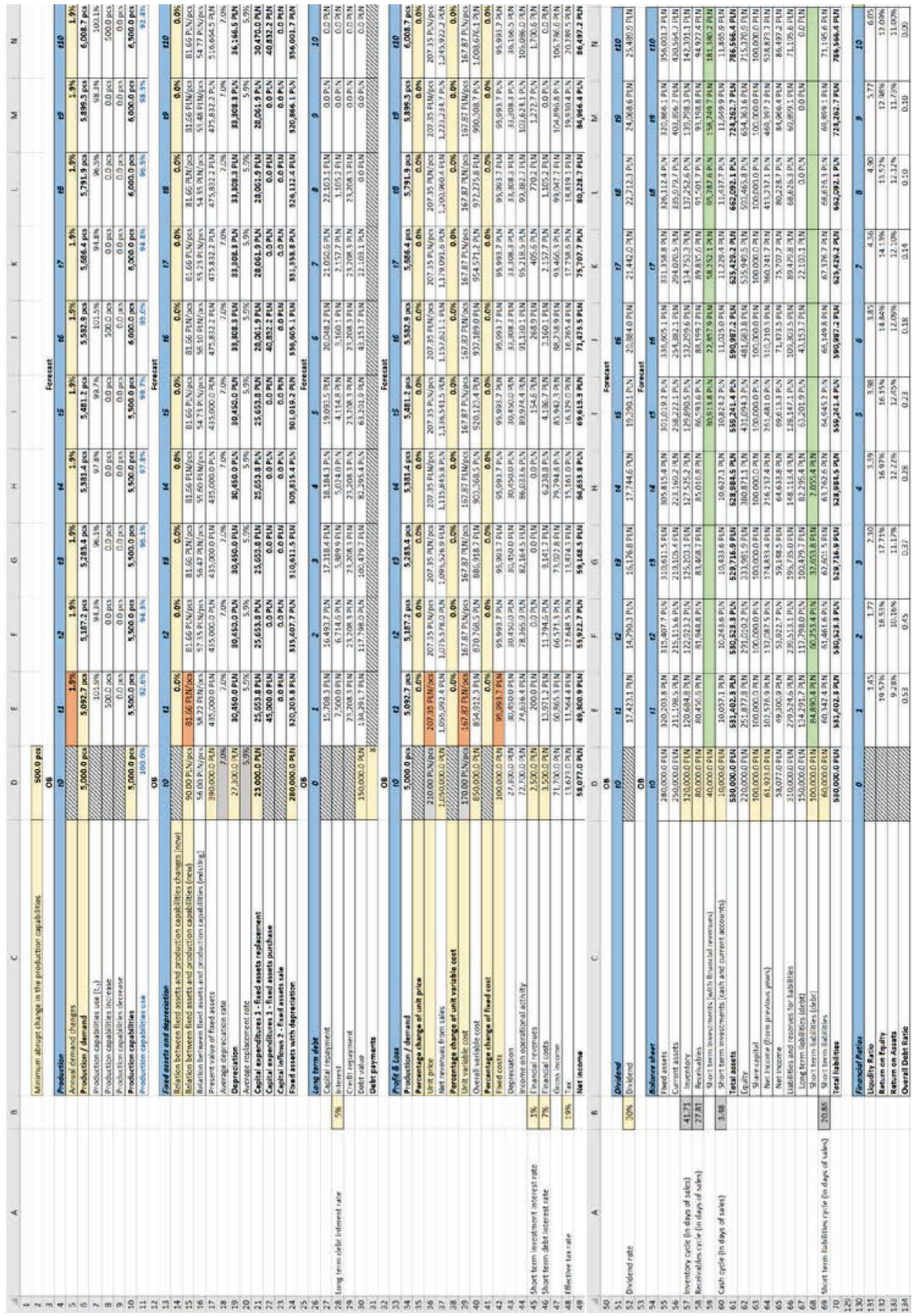

